\title{
Energetics of spider crab Hyas araneus megalopa in relation to temperature and the moult cycle
}

\author{
K. Anger \\ Biologische Anstalt Helgoland, Meeresstation, D-2192 Helgoland, Federal Republic of Germany
}

\begin{abstract}
Megalopa of spider crab Hyas araneus were reared to metamorphosis at 6 and $18^{\circ} \mathrm{C}$, and larval dry weight, carbon, nitrogen, and hydrogen content as well as oxygen consumption were measured at regular intervals during the moult cycle. When larval age is expressed as a percentage of total instar duration, it becomes obvious that the general pattern of growth (bell-shaped curves) is not influenced by temperature: all measures of biomass increase during the postmoult and intermoult stages of the moult cycle, reach maximum values in early premoult, and decrease again during later premoult. Also maximum and final biomass values are similar at the 2 temperatures. Conversion of elemental composition to biochemical data suggests that both protein and lipid are utilized as metabolic substrates during the premetamorphic phase of 'negative growth', but relatively more lipid is catabolized at 18 than at $6^{\circ} \mathrm{C}$. Rates of oxygen consumption are strongly influenced by both temperature and the stage of the moult cycle. At 6 and $12{ }^{\circ} \mathrm{C}$ individual respiration rates $(R)$ decrease during postmoult (the $12^{\circ} \mathrm{C}$ values were taken from another study for comparison), then increase, and eventually decrease again in late premoult. At $18^{\circ} \mathrm{C}$ there is an almost steady decrease in $R$ during the entire moult cycle. Both assimilation $(A)$ and growth $(G)$ rate (in units $C^{-1}$ ) decrease steadily during megalopa development, regardless of temperature. In Stage $D_{0}$ of the moult cycle $A$ equals the metabolic demand and thus, $G$ becomes zero. During later premoult stages, $G$ is negative, and $A$ becomes zero prior to metamorphosis. Net growth efficiency $\left(K_{2}\right)$ decreases from ca 45 to $65 \%$ in early postmoult to zero in Stage $D_{0}$.
\end{abstract}

\section{INTRODUCTION}

Growth patterns of decapods during single larval moult cycles have been analysed in only a few species (Pagurus bernhardus: Dawirs 1981; Hyas araneus: Anger \& Dawirs 1982, Anger \& Jacobi 1985; H. coarctatus: Jacobi \& Anger 1985a; Carcinus maenas: Dawirs 1983, 1986, Dawirs et al. 1986; Nephrops norvegicus: Anger \& Püschel 1986), and only Dawirs et al. (1986) described effects of temperature on those growth patterns.

In Hyas spp. patterns of growth and metabolism during the moult cycle of the megalopa stage were found to differ from those during the zoeal stages (Anger \& Jacobi 1985, Jacobi \& Anger 1985a). While all previous measurements of its growth had been conducted at an intermediate, fairly optimum temperature $\left(12^{\circ} \mathrm{C}\right)$, in the present investigation measurements were made at extremely low and high temperatures $(6$ and $18^{\circ} \mathrm{C}$ ).

These temperatures are close to the limits tolerated by this larval stage of $H$. araneus. Since $18^{\circ} \mathrm{C}$ is already above its optimum for successful development in the laboratory (Anger 1983a), and is near the maximum temperature at which it was found in plankton samples (Roff et al. 1986), the question is posed whether there are significant alterations in net growth efficiency or other energetic traits at high temperature. Such effects might be expected from adaptations related to the boreal-subarctic distribution of this spider crab species (Christiansen 1969, 1982).

\section{MATERIAL AND METHODS}

Larvae were obtained from a single female Hyas araneus and mass-reared at $12{ }^{\circ} \mathrm{C}$ as described by Anger et al. (1983). When they reached the megalopa stage, they were transferred to net-bottom tubes and then maintained individually (for details see Dawirs 1982 , Kunisch \& Anger 1984) at constant 6 or $18^{\circ} \mathrm{C}$. All larval stages were fed exclusively on freshly hatched Artemia sp. (San Francisco Bay Brand).

Larvae having the same age within the megalopa 
instar were sampled every $2\left(18^{\circ} \mathrm{C}\right)$ or $4 \mathrm{~d}\left(6^{\circ} \mathrm{C}\right)$ for measurements of biomass and respiration. Dry weight $(W)$, carbon $(\mathrm{C})$, nitrogen $(\mathrm{N})$, and hydrogen $(\mathrm{H})$ were measured in 11 to 13 replicate samples of individual megalopae (Tables 1 \& 2), applying standard techniques (Anger et al. 1983). Energy content was estimated from C (Salonen et al. 1976). Approximate amounts of lipid and protein were estimated from C and N, respectively (Anger et al. 1983).

Another subsample of the larvae was used for measurements of respiration at the rearing temperature, applying the Winkler method (see Anger \& Jacobi 1985 for details). Metabolic losses of $C$ were estimated using a conversion factor of $0.3375 \mu \mathrm{g} \mathrm{C} / \mu \mathrm{g} \mathrm{O} \mathrm{O}_{2}$, which is based on a respiratory quotient (RQ) of 0.9 . The latter assumption is derived from the biochemical composition of the larvae (Anger et al. 1983) and of their food (Watanabe et al. 1983) as well as on observations in other zooplankton (Dagg et al. 1982).

This study is based on a total of $258 \mathrm{CHN}$ analyses (with an equal number of megalopae) and 168 measurements of respiration (with a total of 504 megalopae). This does not include another study conducted at $12^{\circ} \mathrm{C}$, results of which are partly used in this paper.

\section{RESULTS}

\section{Growth, elemental and biochemical composition}

Metamorphosis of the megalopa to the juvenile crab began $16 \mathrm{~d}$ (at $18^{\circ} \mathrm{C}$ ) and $38 \mathrm{~d}\left(6^{\circ} \mathrm{C}\right.$ ) after moulting. Sampling was terminated on Days 18 and 40, respec- tively, when most individuals were at least very close to metamorphosis. These times were defined as the average durations of development at the 2 temperatures tested.

Changes of biomass and respiration during the course of megalopa development at 6 and $18^{\circ} \mathrm{C}$ are shown in Tables $1 \& 2$, respectively. The patterns may be described, in general, by the quadratic equation proposed by Anger \& Jacobi (1985):

$$
y=a_{0}+a_{1} t+a_{2} t^{2}
$$

where $y=$ any measure of biomass or metabolism (per individual); $t=$ time of development $(\mathrm{d})_{;}$and $a_{0}, a_{1}$ and $a_{2}=$ fitted constants. These parameters are compiled in Table 3 .

The shape of these growth curves is shown, as an example, for dry weight $(W)$ in Fig. 1 (lower graph). When the time of development is expressed as a percentage of total instar duration, almost identical growth curves are obtained at 6 and $18^{\circ} \mathrm{C}$, with maximum values at ca 55 to $60 \%$ development (Fig. 1 , upper graph). When measures of total organic substances within $W(\mathrm{C}, \mathrm{N}, \mathrm{H}$, or energy) are considered, however, a difference between the 2 growth patterns becomes apparent: during the period of final loss, the values at $18^{\circ} \mathrm{C}$ tended to be consistently slightly lower than those at $6^{\circ} \mathrm{C}$, in particular in $\mathrm{C}$ and energy.

Fig. 2 shows the relative fractions of $\mathrm{C}$ and $\mathrm{N}$, the weight ratio of these elements, and weight-specific energy during the moult cycle. During postmoult and early intermoult ( 2 to $6 \mathrm{~d}$ after moulting at $18^{\circ} \mathrm{C}, 2$ to $12 \mathrm{~d}$ at $6^{\circ} \mathrm{C}$ ) the relative $\mathrm{C}, \mathrm{N}$ and energy figures decreased, while the $\mathrm{C} / \mathrm{N}$ ratio increased. This indi-

Table 1. Hyas araneus megalopa. Growth and metabolism in relation to age (d), at $6{ }^{\circ} \mathrm{C}$. Dry weight (W), carbon (C), nitrogen (N), and hydrogen $(\mathrm{H})$ in $\mu \mathrm{g}$, energy content $(E)$ in $\mathrm{J}_{\text {ind }}^{-1}$; repiration rate $(R)$ in $\mu \mathrm{g} \mathrm{O}_{2}$ ind $^{-1} \mathrm{~h}^{-1}$ Arithmetic means \pm standard deviation; n: number of measurements in $W, C, N, H, E_{i}$ in $R, n=8$

\begin{tabular}{|c|c|c|c|c|c|c|c|c|c|c|c|}
\hline \multirow{2}{*}{ Parameter } & \multicolumn{11}{|c|}{ Age (d) } \\
\hline & 0 & 4 & 8 & 12 & 16 & 20 & 24 & 28 & 32 & 36 & 40 \\
\hline$w$ & $\begin{array}{r}253 \\
\pm 22\end{array}$ & $\begin{array}{r}343 \\
\pm 40\end{array}$ & $\begin{array}{r}447 \\
\pm 54\end{array}$ & $\begin{array}{r}468 \\
\pm 60\end{array}$ & $\begin{array}{r}542 \\
\pm 50\end{array}$ & $\begin{array}{r}535 \\
\pm 57\end{array}$ & $\begin{array}{r}536 \\
\pm 82\end{array}$ & $\begin{array}{r}524 \\
\pm 55\end{array}$ & $\begin{array}{r}475 \\
\pm 44\end{array}$ & $\begin{array}{r}473 \\
\pm 92\end{array}$ & $\begin{array}{r}440 \\
\pm 84\end{array}$ \\
\hline C & $\begin{array}{l}103 \\
\pm 9\end{array}$ & $\begin{array}{r}122 \\
\pm 16\end{array}$ & $\begin{array}{r}144 \\
\pm 19\end{array}$ & $\begin{array}{r}144 \\
\pm 45\end{array}$ & $\begin{array}{r}201 \\
\pm 26\end{array}$ & $\begin{array}{r}194 \\
\pm 27\end{array}$ & $\begin{array}{r}223 \\
\pm 50\end{array}$ & $\begin{array}{r}205 \\
\pm 27\end{array}$ & $\begin{array}{r}186 \\
\pm 24\end{array}$ & $\begin{array}{r}182 \\
\pm 47\end{array}$ & $\begin{array}{r}147 \\
\pm 36\end{array}$ \\
\hline $\mathrm{N}$ & $\begin{array}{r}23.8 \\
\pm 2.3\end{array}$ & $\begin{array}{r}26.4 \\
\pm 2.7\end{array}$ & $\begin{array}{r}27.1 \\
\pm 3.7\end{array}$ & $\begin{array}{r}33.0 \\
\pm 4.3\end{array}$ & $\begin{array}{r}38.7 \\
\pm 4.5\end{array}$ & $\begin{array}{r}38.2 \\
\pm 4.8\end{array}$ & $\begin{array}{r}46.6 \\
\pm 7.3\end{array}$ & $\begin{array}{r}42.1 \\
\pm 4.2\end{array}$ & $\begin{array}{r}40.6 \\
\pm 4.2\end{array}$ & $\begin{array}{r}38.4 \\
\pm 7.8\end{array}$ & $\begin{array}{r}33.3 \\
\pm 6.8\end{array}$ \\
\hline $\mathrm{H}$ & $\begin{array}{r}14.3 \\
\pm 2.7\end{array}$ & $\begin{array}{r}17.5 \\
\pm 3.3\end{array}$ & $\begin{array}{r}20.3 \\
\pm 3.4\end{array}$ & $\begin{array}{r}21.4 \\
\pm 7.5\end{array}$ & $\begin{array}{r}29.2 \\
\pm 5.3\end{array}$ & $\begin{array}{r}27.9 \\
\pm 4.9\end{array}$ & $\begin{array}{r}37.4 \\
\pm 8.6\end{array}$ & $\begin{array}{r}29.4 \\
\pm 4.9\end{array}$ & $\begin{array}{r}32.2 \\
\pm 4.0\end{array}$ & $\begin{array}{r}25.8 \\
\pm 8.5\end{array}$ & $\begin{array}{r}21.6 \\
\pm 6.4\end{array}$ \\
\hline$E$ & $\begin{array}{r}3.8 \\
\pm 0.4\end{array}$ & $\begin{array}{r}4.2 \\
\pm 0.6\end{array}$ & $\begin{array}{r}4.8 \\
\pm 0.7\end{array}$ & $\begin{array}{r}5.4 \\
\pm 1.0\end{array}$ & $\begin{array}{r}7.1 \\
\pm 1.0\end{array}$ & $\begin{array}{r}6.1 \\
+1.6\end{array}$ & $\begin{array}{r}8.3 \\
\pm 2.2\end{array}$ & $\begin{array}{r}7.4 \\
\pm 1.1\end{array}$ & $\begin{array}{r}6.7 \\
\pm 1.0\end{array}$ & $\begin{array}{r}6.5 \\
\pm 1.9\end{array}$ & $\begin{array}{r}5.0 \\
\pm 1.4\end{array}$ \\
\hline$R$ & $\begin{array}{r}0.64 \\
\pm 0.04\end{array}$ & $\begin{array}{r}0.58 \\
\pm 0.05\end{array}$ & $\begin{array}{r}0.54 \\
\pm 0.05\end{array}$ & $\begin{array}{r}0.67 \\
\pm 0.08\end{array}$ & $\begin{array}{r}0.59 \\
\pm 0.06\end{array}$ & $\begin{array}{r}0.58 \\
\pm 0.09\end{array}$ & $\begin{array}{r}0.64 \\
\pm 0.07\end{array}$ & $\begin{array}{r}0.60 \\
\pm 0.06\end{array}$ & $\begin{array}{r}0.53 \\
\pm 0.07\end{array}$ & $\begin{array}{r}0.48 \\
\pm 0.09\end{array}$ & $\begin{array}{r}0.45 \\
\pm 0.05\end{array}$ \\
\hline$n$ & 12 & 13 & 13 & 13 & 12 & 13 & 12 & 11 & 12 & 12 & 13 \\
\hline
\end{tabular}


Table 2. Hyas araneus megalopa. Growth and metabolism in relation to age (d), at $18^{\circ} \mathrm{C}$. For explanation see Table 1

\begin{tabular}{|c|c|c|c|c|c|c|c|c|c|c|}
\hline \multirow[t]{2}{*}{ Рarameter } & \multicolumn{10}{|c|}{ Age (d) } \\
\hline & 0 & 2 & 4 & 6 & 8 & 10 & 12 & 14 & 16 & 18 \\
\hline$W$ & $\begin{array}{r}253 \\
\pm 22\end{array}$ & $\begin{array}{r}414 \\
\pm 54\end{array}$ & $\begin{array}{r}448 \\
\pm 53\end{array}$ & $\begin{array}{r}524 \\
\pm 61\end{array}$ & $\begin{array}{r}562 \\
\pm 63\end{array}$ & $\begin{array}{r}520 \\
\pm 61\end{array}$ & $\begin{array}{r}489 \\
\pm 72\end{array}$ & $\begin{array}{r}516 \\
\pm 56\end{array}$ & $\begin{array}{r}440 \\
\pm 76\end{array}$ & $\begin{array}{r}432 \\
\pm 67\end{array}$ \\
\hline $\mathrm{C}$ & $\begin{array}{l}103 \\
\pm 9\end{array}$ & $\begin{array}{r}140 \\
\pm 20\end{array}$ & $\begin{array}{r}157 \\
+24\end{array}$ & $\begin{array}{r}174 \\
+28\end{array}$ & $\begin{array}{r}212 \\
\pm 32\end{array}$ & $\begin{array}{r}174 \\
+29\end{array}$ & $\begin{array}{r}173 \\
+35\end{array}$ & $\begin{array}{r}175 \\
+24\end{array}$ & $\begin{array}{r}146 \\
\pm 32\end{array}$ & $\begin{array}{r}144 \\
+29\end{array}$ \\
\hline $\mathrm{N}$ & $\begin{array}{r}23.8 \\
\pm 2.3\end{array}$ & $\begin{array}{r}28.6 \\
\pm 3.1\end{array}$ & $\begin{array}{r}32.0 \\
\pm 4.3\end{array}$ & $\begin{array}{r}36.3 \\
\pm 5.9\end{array}$ & $\begin{array}{r}39.8 \\
+12.4\end{array}$ & $\begin{array}{r}40.2 \\
\pm 5.1\end{array}$ & $\begin{array}{r}37.1 \\
\pm 6.9\end{array}$ & $\begin{array}{r}38.3 \\
\pm 4.2\end{array}$ & $\begin{array}{r}33.4 \\
\pm 6.3\end{array}$ & $\begin{array}{r}32.2 \\
\pm 6.6\end{array}$ \\
\hline $\mathrm{H}$ & $\begin{array}{r}14.3 \\
\pm 2.7\end{array}$ & $\begin{aligned} & 20.5 \\
\pm & 3.6\end{aligned}$ & $\begin{array}{r}23.8 \\
\pm 5.2\end{array}$ & $\begin{array}{r}24.6 \\
\pm 4.9\end{array}$ & $\begin{array}{r}30.3 \\
\pm 5.3\end{array}$ & $\begin{array}{r}23.8 \\
\pm 4.9\end{array}$ & $\begin{array}{r}27.0 \\
\pm 5.7\end{array}$ & $\begin{array}{r}27.1 \\
\pm \quad 3.6\end{array}$ & $\begin{array}{r}21.8 \\
\pm 5.2\end{array}$ & $\begin{array}{r}21.8 \\
\pm 4.7\end{array}$ \\
\hline$E$ & $\begin{array}{r}3.8 \\
+0.4\end{array}$ & $\begin{array}{r}4.8 \\
\pm 0.7\end{array}$ & $\begin{array}{r}5.4 \\
\pm 0.9\end{array}$ & $\begin{array}{r}5.9 \\
\pm 1.0\end{array}$ & $\begin{array}{r}7.6 \\
+1.4\end{array}$ & $\begin{array}{r}5.9 \\
\pm 1.1\end{array}$ & $\begin{array}{r}6.0 \\
+1.3\end{array}$ & $\begin{array}{r}6.0 \\
\pm 0.9\end{array}$ & $\begin{array}{r}4.9 \\
\pm 1.2\end{array}$ & $\begin{array}{r}4.9 \\
+1.1\end{array}$ \\
\hline$R$ & $\begin{array}{r}1.29 \\
\pm 0.10\end{array}$ & $\begin{array}{r}1.26 \\
\pm 0.07\end{array}$ & $\begin{array}{r}1.20 \\
\pm 0.11\end{array}$ & $\begin{array}{r}1.05 \\
\pm 0.14\end{array}$ & $\begin{array}{r}1.11 \\
\pm 0.10\end{array}$ & $\begin{array}{r}1.08 \\
\pm 0.07\end{array}$ & $\begin{array}{r}0.97 \\
\pm 0.07\end{array}$ & $\begin{array}{r}1.10 \\
\pm 0.18\end{array}$ & $\begin{array}{r}0.81 \\
\pm 0.12\end{array}$ & $\begin{array}{r}0.75 \\
\pm 0.08\end{array}$ \\
\hline $\mathrm{n}$ & 12 & 12 & 12 & 12 & 12 & 13 & 13 & 12 & 12 & 12 \\
\hline
\end{tabular}

Table 3. Hyas araneus megalopa. Fitted constants $\left(a_{0}, a_{1}, a_{2}\right)$ and coefficient of determination $\left(r^{2}\right)$ for Eqn (1) describing: growth in dry weight $(W)$, carbon $(C)$, nitrogen $(\mathrm{N})$, hydrogen $(\mathrm{H})$ (all in $\mathrm{mg})$, and energy $\left(E, \mathrm{~J}\right.$ ind $\left.^{-1}\right)$, and the course of respiration $(R, \mu g$ $\mathrm{O}_{2}$ ind $^{-1} \mathrm{~h}^{-1}$ ), in relation to age (d). $R_{1}$ : respiration during first; $R_{2}$ : during second half of the moult cycle

\begin{tabular}{|c|c|c|c|c|c|c|c|c|}
\hline \multirow[t]{2}{*}{ Parameter } & \multicolumn{4}{|c|}{$6{ }^{\circ} \mathrm{C}$} & \multicolumn{4}{|c|}{$18^{\circ} \mathrm{C}$} \\
\hline & $a_{0}$ & $a_{1}$ & $a_{2}$ & $r^{2}$ & $a_{0}$ & $a_{1}$ & $a_{2}$ & $r^{2}$ \\
\hline$W$ & 0.267 & 0.0231 & -0.000484 & 0.952 & 0.292 & 0.0488 & -0.00238 & 0.874 \\
\hline $\mathrm{C}$ & 0.0894 & 0.00925 & -0.000190 & 0.874 & 0.108 & 0.0161 & -0.000818 & 0.824 \\
\hline$N$ & 0.0206 & 0.00158 & -0.0000304 & 0.858 & 0.0234 & 0.00300 & -0.000142 & 0.952 \\
\hline $\mathrm{H}$ & 0.0116 & 0.00157 & -0.0000318 & 0.802 & 0.0154 & 0.00235 & -0.000115 & 0.799 \\
\hline$E$ & 3.2 & 0.328 & -0.00671 & 0.796 & 3.8 & 0.536 & -0.0277 & 0.765 \\
\hline $\bar{R}_{1}$ & 0.632 & -0.0146 & 0.000627 & 0.839 & 1.309 & -0.0413 & 0.00162 & 0.813 \\
\hline$R_{2}$ & 0.326 & 0.0251 & -0.000562 & 0.870 & 0.820 & 0.0656 & -0.00388 & 0.790 \\
\hline
\end{tabular}

cates that more inorganic than organic matter and, within the latter, more lipid than protein were accumulated during this phase of the moult cycle, independent of temperature. During premoult (the second half of the moult cycle) the percentage of $\mathrm{C}$ and $\mathrm{H}$, the $\mathrm{C} / \mathrm{N}$ ratio, and weight-specific energy were in general higher at 6 than at $18^{\circ} \mathrm{C}$.

Approximate lipid and protein contents may be estimated from these $\mathrm{C}$ and $\mathrm{N}$ values (Anger et al. 1983). Very similar curves as for dry weight (Fig. 1) are obtained from these conversions. They indicate that there are high gains in both constituents during postmoult and intermoult, and that maximum values occur when $W$ is also maximum (after ca $60 \%$ of moult cycle duration). Estimates of both lipid and protein during the premoult phase of biomass loss are consistently higher at 6 than at $18^{\circ} \mathrm{C}$ with a greater difference in lipid than in protein. Lipid/protein weight ratios reveal an increase in postmoult and a decrease in premoult, with almost consistently higher values at $6^{\circ} \mathrm{C}(0.32$ to $0.36)$ than at $18^{\circ} \mathrm{C},(0.31$ to 0.34$)$. When lipid and protein values are expressed as a percentage of $W$, they indicate that at $18^{\circ} \mathrm{C}$, as compared to $6^{\circ} \mathrm{C}$, relatively more lipid than protein is utilized during premoult (Fig. 3).

\section{Metabolism}

Individual respiration rates of megalopa reared at 6 and $18^{\circ} \mathrm{C}$ are given in Tables $1 \& 2$, respectively. Their patterns of change during development are shown and compared directly in Fig. 4. Values obtained at $12^{\circ} \mathrm{C}$ were taken for comparison from a different study (Hirche \& Anger in press) which was conducted in the same season and with identical methods, but with megalopae from a different female. These larvae had, in general, a somewhat higher biomass than those reared at 6 and $18^{\circ} \mathrm{C}$.

Respiration curves were similar in shape at 6 and $12{ }^{\circ} \mathrm{C}$, but almost constantly decreasing at $18^{\circ} \mathrm{C}$ (Fig. 4). These patterns may in all cases be described by 2 quadratic equations [same type as in biomass, Eqn 


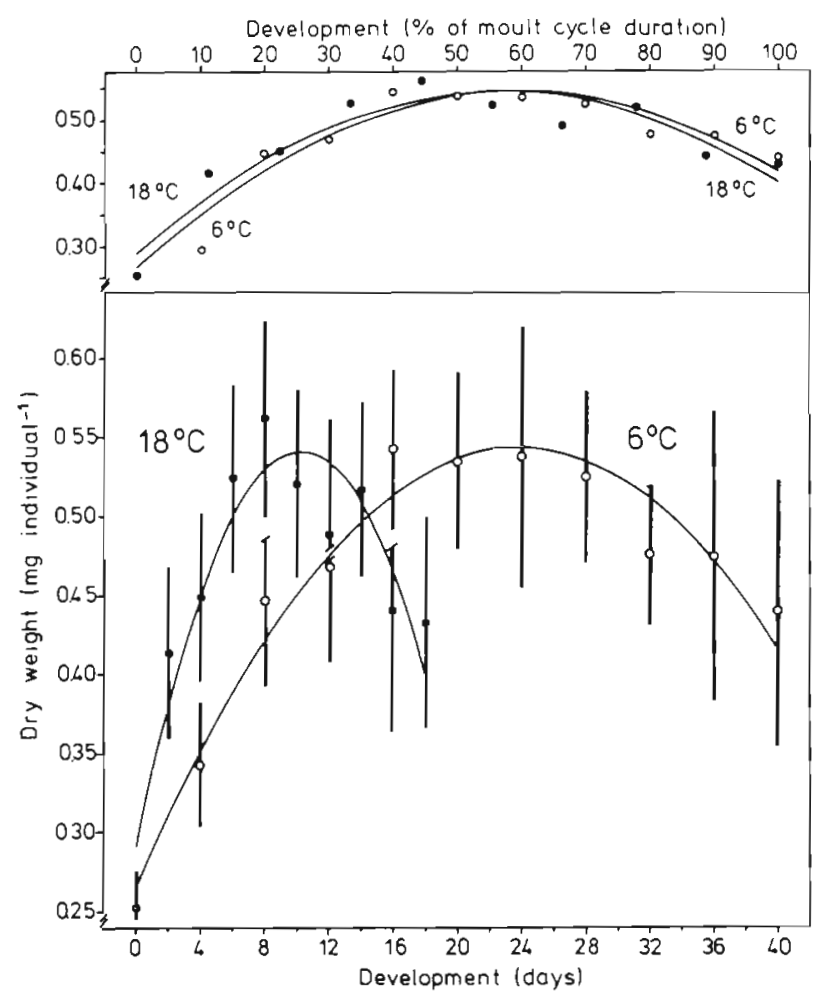

Fig. 1. Hyas araneus megalopa. Dry weight during development at 6 and $18^{\circ} \mathrm{C}$. Lower graph: mean values \pm standard deviation

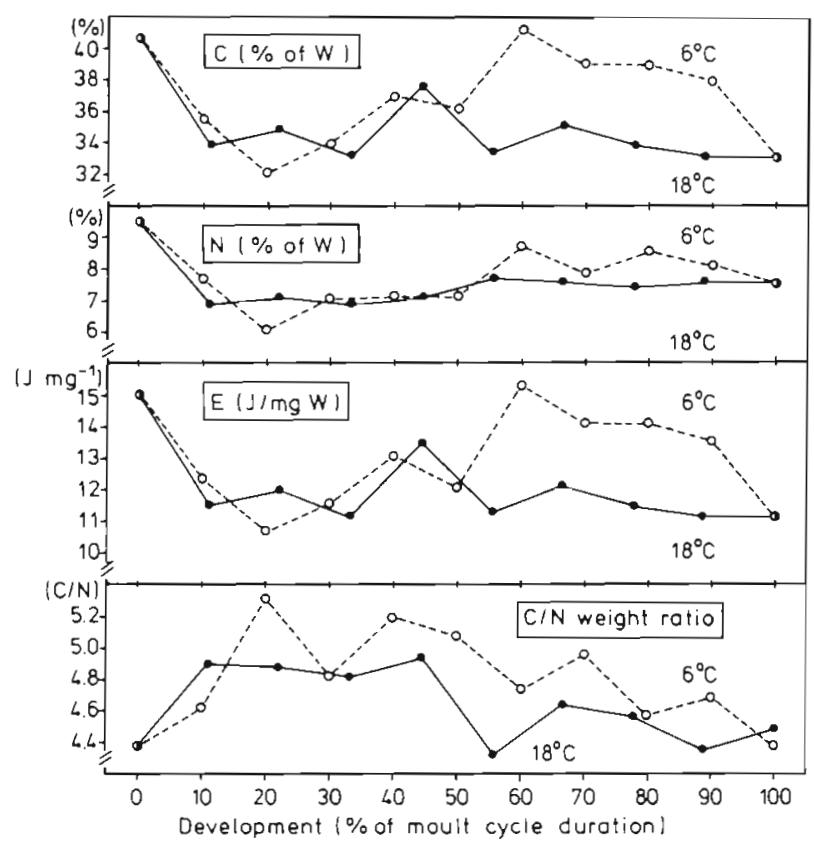

Fig. 2. Hyas araneus megalopa. Carbon (C), nitrogen (N) $1 \%$ of dry weight, $W$ ), weight-specific energy content $\left(\mathrm{J} \mathrm{mg}^{-1} W\right.$; estimated from C: Salonen et al. 1976), and C/N weight ratio during development at 6 and $18^{\circ} \mathrm{C}$

(1)], for the first and second half of the moult cycle, respectively (Table 3). Direct comparison of metabolic changes during development is possible in Fig. 4 (upper graph), where time is expressed in relative

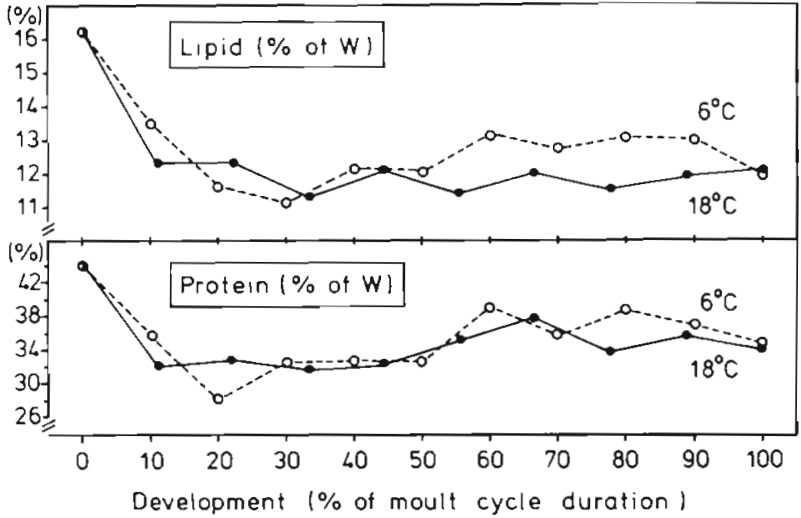

Fig. 3. Hyas araneus megalopa. Lipid and protein content $(\%$ of dry weight, $W$; estimated from carbon and nitrogen, respectively: Anger et al. 1983) during development at 6 and $18^{\circ} \mathrm{C}$

units (\% of moult cycle duration). From these curves the temperature quotient $\left(Q_{10}\right)$ for the range 6 to $18^{\circ} \mathrm{C}$ may be calculated. Its course shows a sinusoidal pattern inversely related in shape to the respiration curves at 6 and $12{ }^{\circ} \mathrm{C}$. During the first half of the moult cycle, $Q_{10}$ values were high (1.8 to 1.9 ), then they decreased to ca 1.5 to 1.6 , i.e. effects of temperature changes on larval metabolism were in general lower in

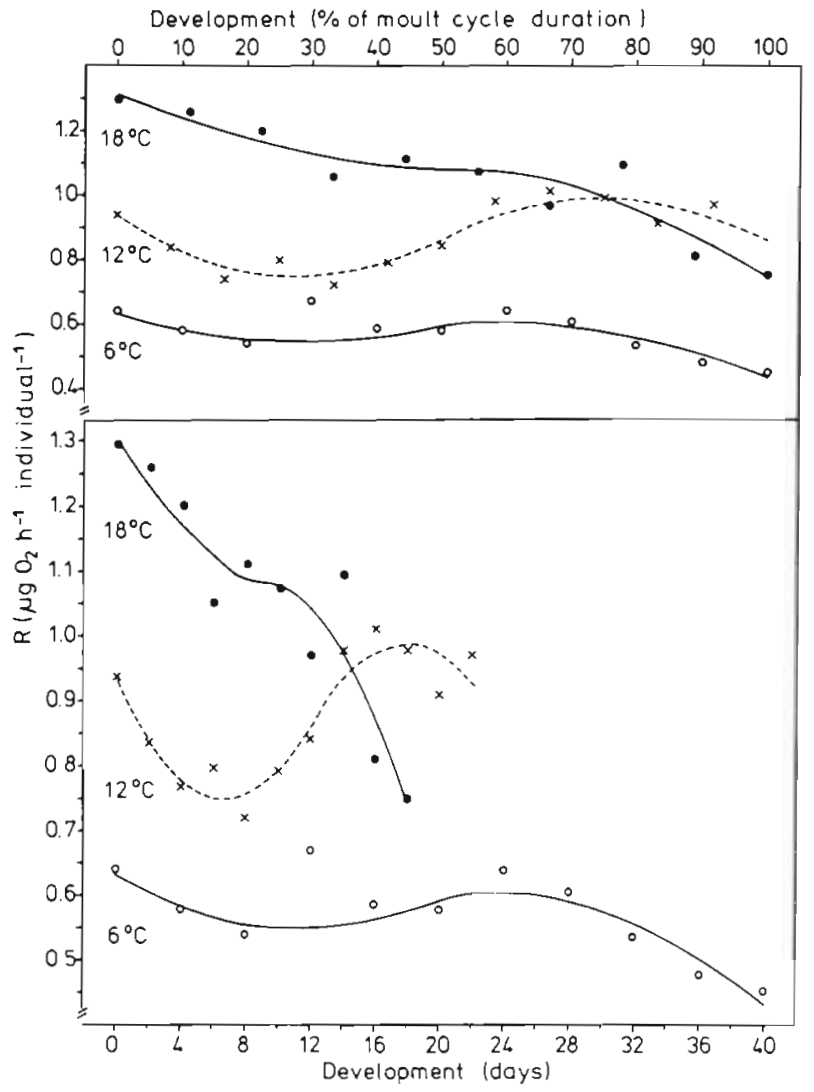

Fig. 4. Hyas araneus megalopa. Individual respiration rate $(R)$ during development at 6,12 and $18{ }^{\circ} \mathrm{C}\left(12{ }^{\circ} \mathrm{C}\right.$ values from larvae from a different hatch) 


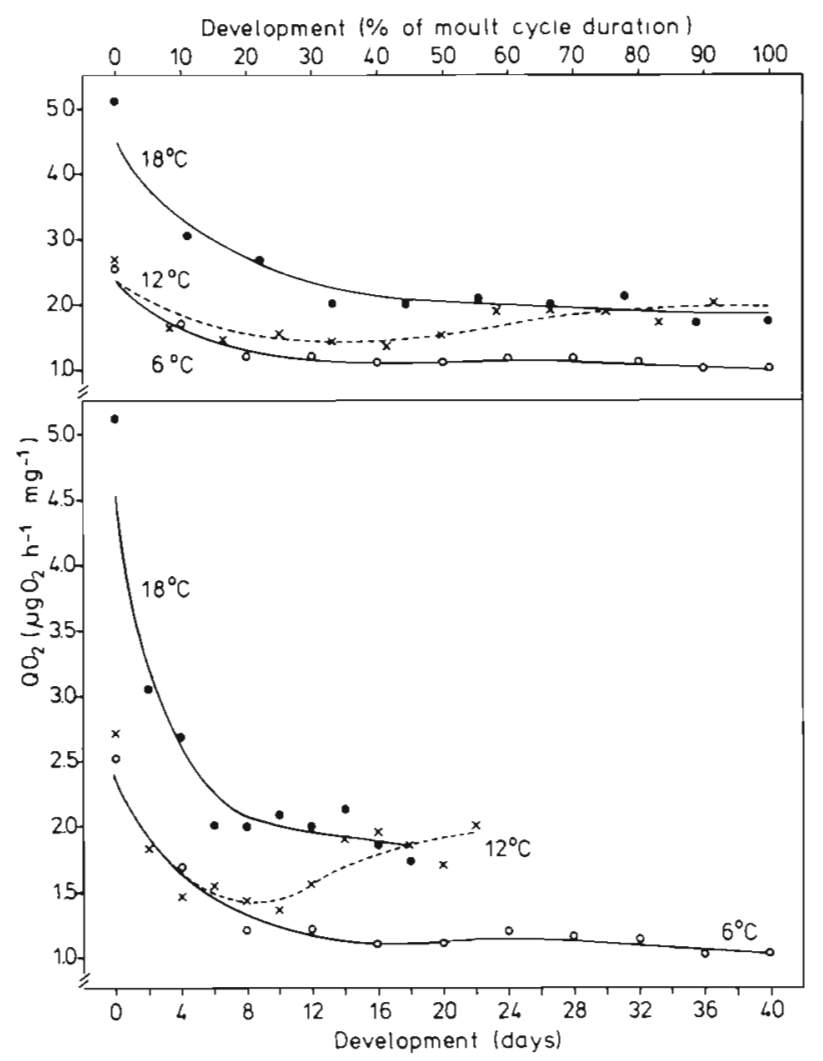

Fig. 5. Hyas araneus megalopa. Weight-specific respiration rate $\left(Q_{2}\right)$ during development at 6,12 and $18^{\circ} \mathrm{C}\left(12^{\circ} \mathrm{C}\right.$ values from larvae from a different hatch)

the second than in the first half of megalopa development. This was particularly obvious in the range between 12 and $18^{\circ} \mathrm{C}$, where $Q_{10}$ decreased during premoult to values around 1.0. In the lower temperature range $\left(6\right.$ to $\left.12{ }^{\circ} \mathrm{C}\right)$, however, rather the opposite trend may be seen, with lowest $Q_{10}$ values in early postmoult and highest in late premoult.

Weight-specific respiration rates $\left(Q_{2}\right)$ during megalopa development are shown in Fig. 5. At all 3 temperatures compared there was a conspicuous decrease during postmoult and intermoult, followed by constantly low $\left(6^{\prime} 18^{\circ} \mathrm{C}\right)$ or increasing values $\left(12^{\circ} \mathrm{C}\right)$. The relative positions of the $\mathrm{QO}_{2}$ curves in the upper graph of Fig. 5 indicate again that temperature changes within the lower range $\left(6\right.$ to $\left.12^{\circ} \mathrm{C}\right)$ have very little influence on metabolism of early postmoult megalopae $\left(Q_{10}\right.$ near 1.0) whereas increased temperatures $\left(12\right.$ to $\left.18^{\circ} \mathrm{C}\right)$ have a strong effect. Later in development, in premoult, the opposite trend may be seen $\left(Q_{10}\right.$ near 1.0 in the upper temperature range).

\section{Net growth efficiency $\left(K_{2}\right)$}

When rates of growth (G) and metabolism $(M)$ are converted to units of carbon or energy per day, assimilation $(A)$ and net growth efficiency $\left(K_{2}\right)$ can be calcu- lated on a daily basis during megalopa development (Fig. 6: C-based budgets shown as an example). Variation in $M$ appears quite low as compared to that in $A$ and $G$. Assimilation and growth rates decreased, regardless of temperature, during postmoult and intermoult, and G became zero when ca 55 to $60 \%$ of moult cycle duration had elapsed. Thereafter, during premoult (dashed lines in Fig. 6), assimilation was lower than metabolic demand, and growth rates became negative. In late premoult (after 80 to $90 \%$ of total development time), losses became theoretically greater than can be accounted for by metabolism. It cannot be determined yet whether this is an artifact of the models of growth and respiration used here, or if there are carbon losses other than by respiration (see 'Discussion').

When the complete instar was considered, similar total net growth values (ca 44,54, and $41 \mu \mathrm{g} \mathrm{C}$ ) were

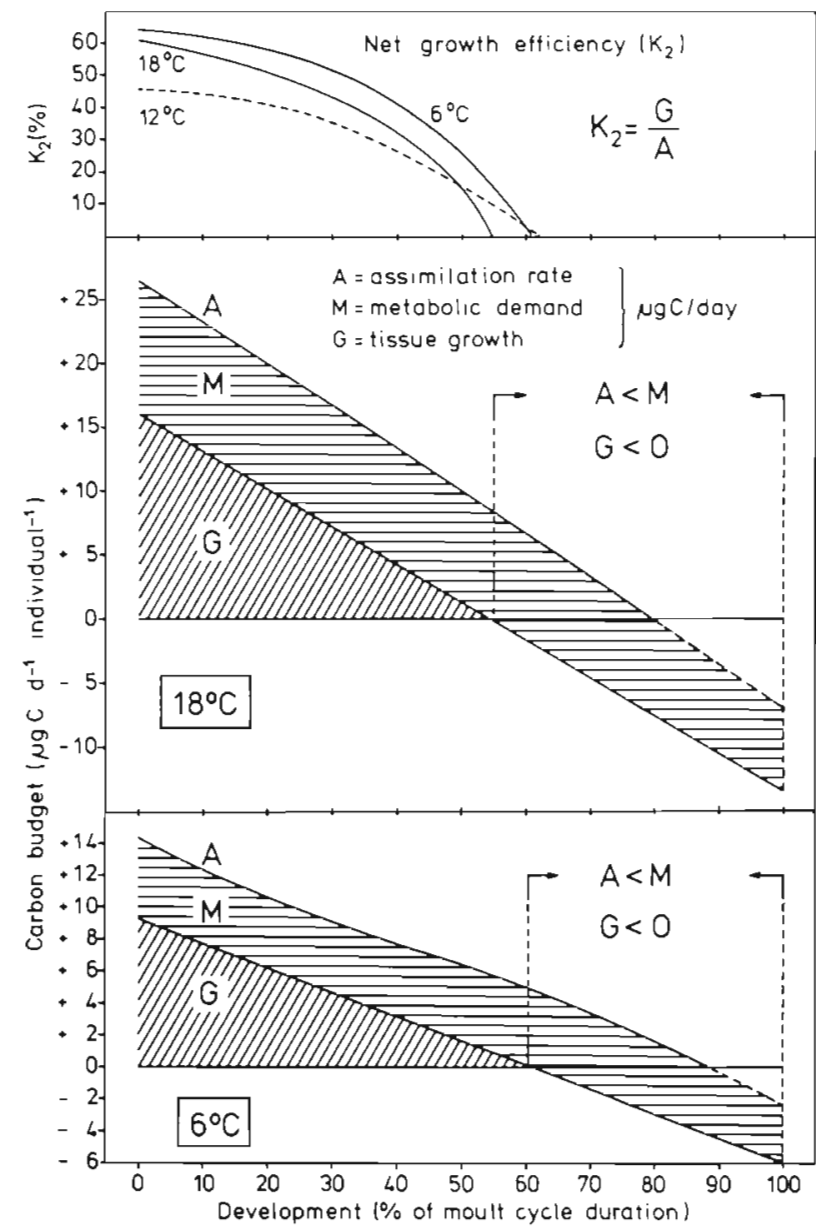

Fig. 6. Hyas araneus megalopa. Partial carbon budget during development at 6 and $18^{\circ} \mathrm{C}$ (lower and middle graph), and net growth efficiency $\left(K_{2}\right)$ at 6,12 and $18^{\circ} \mathrm{C}$ (upper graph) $\left(12{ }^{\circ} \mathrm{C}\right.$ values from larvae from a different hatch). Dashed vertical lines and arrows: premoult period of development, where assimilation (A) falls short of metabolic demand (M) and thus, tissue growth $(G)$ is negative 
found at 6,12 , and $18^{\circ} \mathrm{C}$, respectively (Tables $1 \& 2$ ). Metabolic losses at these temperatures were calculated as 182, 170 , and $115 \mu \mathrm{g} C$ during the entire megalopa instar (obtained by integration of respiration curves, Fig. 4; constants in Table 3; conversion to $\mathrm{C}$ values, assuming an $\mathrm{RQ}=0.9$ ). Net growth efficiency of the megalopa was thus estimated as 20,24 , and $21 \%$ at 6,12 , and $18{ }^{\circ} \mathrm{C}$, respectively. These figures cannot be considered significantly different, since actual net growth is estimated only roughly by calculating the difference between initial and final carbon values, and the $12{ }^{\circ} \mathrm{C}$ megalopae originated from a different female. This suggests that $K_{2}$ is not significantly influenced by temperature. In total $A, G$ and $M$ values (see above), however, there was a slight decreasing tendency with increasing temperature.

When $K_{2}$ was calculated from the above models of growth and respiration (Fig. 4, Table 3) on a daily basis, similar patterns were found at all 3 temperatures: $K_{2}$ values decreased from ca 45 to $65 \%$ in early postmoult, to zero when ca 55 to $60 \%$ of the megalopa moult cycle had elapsed, and then became negative. This energetic trait of the ultimate larval instar of Hyas araneus appeared little influenced by temperature (Fig. 6, upper graph).

\section{DISCUSSION}

The typical bell-shaped biomass growth pattern of the megalopa which had already been observed but considered with reservation by Anger \& Dawirs (1982), was found again in the present study (Fig. 1). It is consistent with results obtained in other recent studies on Hyas araneus (Anger et al. 1983, Anger \& Jacobi 1985), H. coarctatus (Jacobi \& Anger 1985a), and Carcinus maenas (Dawirs et al. 1986). In all these instances, the megalopa ceased to grow when a little more than half (ca 50 to $60 \%$ ) of the entire moult cycle duration had passed. Thus, it might be a common growth pattern in the ultimate larval stage of brachyurans.

Losses of biomass and energy during premoult are partly accompanied or caused by reduced feeding rates (Anger \& Dietrich 1984, Dawirs \& Dietrich 1986). Assimilation (Fig. 6) may not then be sufficient to meet the metabolic demand for internal reconstruction processes preparing metamorphosis to the first juvenile. If there is complete food deprivation during this premetamorphic developmental phase, however, losses of biomass are greater than in continually fed megalopae (Anger et al. 1983). This also indicates that feeding and assimilation do not cease completely when maximum biomass is reached.

The relative time when maximum biomass and energy in the megalopa of Hyas araneus are reached (ca 55 to $60 \%$ of instar duration) corresponds to that of the early premoult $\left(D_{0}\right)$ stage of the moult cycle (Anger 1983b). This stage has recently been identified as a critical point which, when reached under good feeding conditions, will allow potentially autonomous (foodindependent) development through the rest of the moult cycle (Anger 1984). Anger \& Spindler (in press) suggested that essential substances (probably sterols) have reached a critical pool size in this stage, so that sufficient amounts of the moulting hormone can be synthesized, regardless of further absence or presence of food. The megalopa shows 'negative growth' after this point of development, i.e. assimilation rate becomes smaller than the respiratory losses (Fig, 6), whereas moulting hormones reach their peak concentration later in premoult (Spindler \& Anger 1986).

It is interesting to note that other physiological traits of the megalopa also appear to change after passing the ' $\mathrm{D}_{0}$ threshold' (Anger 1984): respiration rate (only at temperatures below $18^{\circ} \mathrm{C}$ ) increases and approaches a maximum (Fig. 4), whereas digestive enzyme activities decrease to a minimum (Hirche \& Anger in press). These parallel findings again emphasize the particular significance of Stage $D_{0}$ within the moult cycle of larval decapods.

In late premoult, when 80 to $90 \%$ of the megalopa moult cycle has been passed, assimilation rate approaches zero (Fig. 6). Further increase in daily losses of biomass and energy may be an artifact caused by our simple growth model. There might also, however, be other sources of carbon loss prior to metamorphosis, in addition to respiration: increased excretion of urea, amino acids, or of other organic substances. This problem will have to be analysed in more detail in future studies on megalopa physiology and biochemistry.

The present results have shown that temperature, even when extremely high or low, does not significantly alter the dry weight growth pattern, as long as it still allows development (Fig. 1, upper graph), When biochemical composition of the megalopa is considered, however, a temperature effect becomes apparent: carbon and nitrogen data strongly suggest that at high temperature $\left(18^{\circ} \mathrm{C}\right)$ relatively more lipid and less protein are catabolized during the premoult phase of the megalopa.

The respiration curve is also changed at $18^{\circ} \mathrm{C}$ (Fig. 4), possibly indicating a stress condition. Weightspecific respiration rates during premoult (Fig. 5) are equally high at 12 and $18^{\circ} \mathrm{C}\left(Q_{10}=1.0\right)$. Lack of increase or even a decrease in metabolic rates has often been found when enhanced temperatures approached the upper limit of tolerance (e.g. Schatzlein \& Costlow 1978, Vernberg et al. 1981). This is 
probably what happened at $18^{\circ} \mathrm{C}$. In the field (German Bight) the megalopa should normally encounter temperatures ranging from ca 5 to $13{ }^{\circ} \mathrm{C}$ (Anger 1983a).

Changes of the $Q_{10}$ value during a single moult cycle show that this potential source of error should be taken into consideration in studies of temperature effects on larval metabolism, i.e. larvae should be moult-staged. Short-term changes are particularly significant in weight-specific respiration rate during postmoult (Fig. 5). Jacobi \& Anger (1985b) measured a $Q_{10}$ of 1.8 for late intermoult megalopae of Hyas araneus in the temperature range 6 to $18^{\circ} \mathrm{C}$. This is very close to the present results $(1.7$ in the same stage of the moult cycle, after ca $50 \%$ of instar duration).

The present results (Fig. 6) suggest that the general bioenergetic traits of the megalopa, in particular its net growth efficiency, are not significantly changed by extremely high or low temperature. Significantly increased mortality at $18^{\circ} \mathrm{C}$ (Anger 1983a) thus cannot be explained by a simple failure to assimilate or to convert sufficient amounts of matter and energy. Total values of assimilation, net growth, and metabolism are similar at 6,12 , and $18{ }^{\circ} \mathrm{C}$. Since mortality at unsuitably high temperature becomes particularly obvious when metamorphosis is imminent, this suggests that some enzymatic or hormonal system involved in the regulation of late moult cycle events may be disturbed. Future studies will concentrate further on such presumable interactions between environmental variables, parameters of bioenergetic budgets and systems controlling developmental and other physiological processes in the larval development of decapod crustaceans.

Acknowledgements. This study is a contribution to research project An-145/1-2 granted by the Deutsche Forschungsgemeinschaft. Ms C. Püschel carried out the $\mathrm{CHN}$ analyses, Mrs B. Köhn helped in experiments and made the line drawings, and Dr E. Wahl and Mr M. Janke provided Artemia.

\section{LITERATURE CITED}

Anger, K. (1983a). Temperature and the larval development of Hyas araneus L. (Decapoda: Majidae); extrapolation of laboratory data to field conditions. J. exp. mar. Biol. Ecol. 69: 203-215

Anger, K. (1983b). Moult cycle and morphogenesis in Hyas araneus larvae (Decapoda, Majidae), reared in the laboratory. Helgoländer Meeresunters. 36: 285-302

Anger, K. (1984). Influence of starvation on moult cycle and morphogenesis of Hyas araneus larvae (Decapoda, Majidae). Helgoländer Meeresunters. 38: 21-33

Anger, K., Dawirs, R. R. (1982). Elemental composition (C, N, $\mathrm{H})$ and energy in growing and starving larvae of Hyas araneus (Decapoda, Majidae). Fish. Bull. U.S. 80: 419-433

Anger, K., Dietrich, A. (1984). Feeding rates and gross growth efficiencies in Hyas araneus L. larvae (Decapoda: Majidae) reared in the laboratory. J. exp. mar. Biol. Ecol. 77: $169-181$
Anger, K., Jacobi, C. C. (1985). Respiration and growth of Hyas araneus L. larvae (Decapoda: Majidae) from hatching to metamorphosis. J. exp. mar. Biol. Ecol. 88: 257-270

Anger, K., Püschel, C. (1986). Growth and exuviation of Norway lobster (Nephrops norvegicus) larvae reared in the laboratory. Ophelia (in press)

Anger, K., Spindler, K.-D. (in press). Energetics, moult cycle, and ecdysteroid titers in spider crab (Hyas araneus) larvae starved after the $\mathrm{D}_{0}$ threshold. Mar. Biol.

Anger, K., Laasch, N., Püschel, C., Schorn, F. (1983). Changes in biomass and chemical composition of spider crab (Hyas araneus) larvae reared in the laboratory. Mar. Ecol. Prog. Ser. 12: 91-101

Christiansen, M. E. (1969). Crustacea, Decapoda, Brachyura. Marine Invertebrates of Scandinavia, No. 2. Universitetsvorlaget, Oslo

Christiansen, M. E. (1982). A review of the distribution of Crustacea Decapoda Brachyura in the Northeast Atlantic. Quad. Lab. Tecnol. Pesca 3: 347-354

Dagg, M. J., Vidal, J., Whitledge, T. E., Iverson, R. L., Goering, J. J. (1982). The feeding, respiration, and excretion of zooplankton in the Bering Sea during a spring bloom. Deep Sea Res. 29: 45-63

Dawirs, R. R. (1981). Elemental composition (C, N, H) and energy in the development of Pagurus bernhardus (Decapoda: Paguridae) megalopa. Mar. Biol. 64: 117-123

Dawirs, R. R. (1982). Methodical aspects of rearing decapod larvae, Pagurus bernhardus (Paguridae) and Carcinus maenas (Portunidae). Helgoländer Meeresunters. 35: $439-464$

Dawirs, R. R. (1983). Respiration, energy balance and development during growth and starvation of Carcinus maenas L. larvae (Decapoda: Portunidae). J. exp. mar. Biol. Ecol. 69: 105-128

Dawirs, R. R. (1986). Influence of limited food supply on growth and elemental composition ( $C, N, H)$ of Carcinus maenas (Decapoda) larvae, reared in the laboratory. Mar. Ecol. Prog. Ser. 31: 301-308

Dawirs, R. R., Dietrich, A. (1986). Temperature and laboratory feeding rates in Carcinus maenas L. (Decapoda: Portunidae) larvae from hatching through metamorphosis. J. exp. mar. Biol. Ecol. 99: 133-147

Dawirs, R. R., Püschel, C., Schorn, F. (1986). Temperature and growth in Carcinus maenas L. (Decapoda: Portunidae) larvae reared in the laboratory from hatching through metamorphosis. J. exp. mar. Biol. Ecol. 100: 47-74

Hirche, H. J., Anger, K. (in press). Digestive enzyme activities during larval development of Hyas araneus (Decapoda, Majidae). Comp. Biochem. Physiol.

Jacobi, C. C., Anger, K. (1985a). Growth and respiration during the larval development of Hyas coarctatus (Decapoda: Majidae). Mar. Biol. 87: 173-180

Jacobi, C. C., Anger, K. (1985b). Effect of temperature on respiration of larval stages of Hyas araneus and $H$. coarctatus (Decapoda, Majidae). Mar. Ecol. Prog. Ser. 26: $181-186$

Kunisch, M., Anger, K. (1984). Variation in development and growth rates of larval and juvenile spider crabs Hyas araneus reared in the laboratory. Mar. Ecol. Prog. Ser. 15: 293-301

Roff, J. C., Fanning, L. P., Stasko, A. B. (1986). Distribution and association of larval crabs (Decapoda: Brachyura) on the Scotian Shelf. Can. J. Fish. Aquat. Sci. 43: 587-599

Salonen, K., Sarvala, J., Hakala, I., Viljanen, M.-L. (1976). The relation of energy and organic carbon in aquatic invertebrates. Limnol. Oceanogr. 21: 724-730

Schatzlein, F. C., Costlow, J. D. (1978). Oxygen consumption 
of the larvae of the decapod crustaceans, Emerita talpoida (Say) and Libinia emarginata Leach. Comp. Biochem. Physiol. 61 A: 441-450

Spindler, K.-D., Anger, K. (1986). Ecdysteroid levels during the larval development of the spider crab Hyas araneus. Gen. Comp. Endocrinol. 64: 122-128

Vernberg, W. B., Moreira, G. S., McNamara, J. C. (1981). The effect of temperature on the respiratory metabolism of the developmental stages of Pagurus criniticornis (Dana) (Anomura: Paguridae). Mar. Biol. Lett. 2: 1-9

Watanabe, T., Kitajima, C., Fujita, S. (1983). Nutritional values of live organisms used in Japan for mass propagation of fish: a review. Aquaculture $34: 115-143$

This article was submitted to the editor; it was accepted for printing on December 19, 1986 